\title{
Left atrial myxoma complicated by acute embolism to the left subclavian artery
}

\author{
Arvind Kandoria, ${ }^{1}$ Prakash Negi, ${ }^{1}$ Kunal Mahajan, ${ }^{1}$ Shailja Puri ${ }^{2}$
}

'Department of Cardiology, Indira Gandhi Medical College, Shimla, Himachal Pradesh, India

${ }^{2}$ Indira Gandhi Medical College, Shimla, Himachal Pradesh, India

\section{Correspondence to}

Dr Kunal Mahajan, kunalmahajan442@gmail.com

\section{Accepted 12 May 2016}

\section{DESCRIPTION}

A 65-year-old man presented with acute-onset pain and numbness in the left upper limb for the past 6 hours. On examination, the left upper limb was pale and cold with absent pulses. There was no neurological deficit. The patient was a non-smoker, and had no atherosclerotic risk factors. Cardiac auscultation was normal. Subclavian artery angiography showed multiple filling defects in the proximal segment and total occlusion just after the origin of the vertebral artery (figure 1 and video 1 ). Transthoracic echocardiogram was carried out to assess a possible cardiac source for the embolism. A $0.9 \times 1.2 \mathrm{~cm}$ rounded, heterogeneous, mobile mass

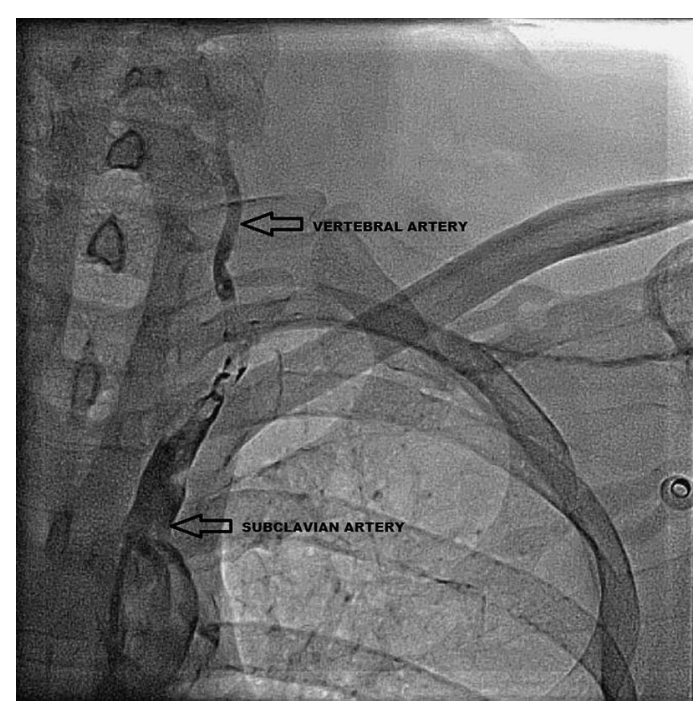

Figure 1 Subclavian artery injection showing a large filling defect in the proximal segment followed by total occlusion just after the origin of the vertebral artery.

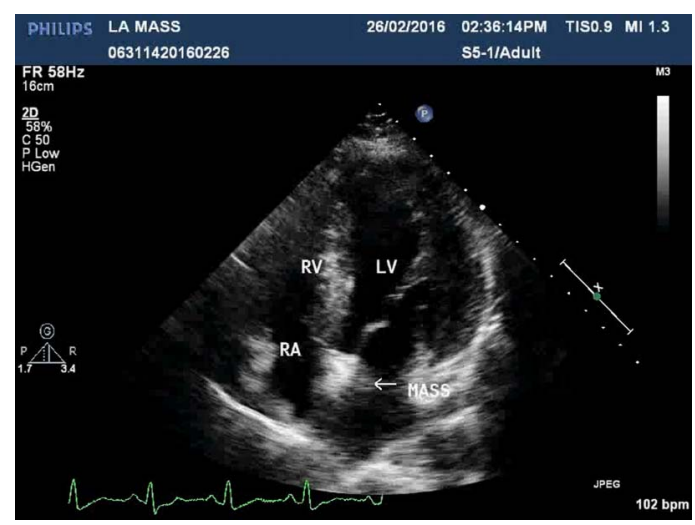

Video 1 Transthoracic echocardiogram, Apical-4chamber view, showing a highly mobile left atrial mass, which appears attached to the interatrial septum. was detected in the left atrium (figure 2 and video 2 ). The mass was attached to the interatrial septum in the region of the fossa ovalis. There was no associated disease of the mitral valve nor of the left ventricle. The location, mobility and echotexture suggested it to be a tumour rather than a thrombus. Urgent concurrent embolectomy of the left upper limb and open heart surgical removal of the cardiac mass were performed to avoid further embolism (figure 3). The diagnosis of atrial myxoma was confirmed by histopathological examination (figure 4). Myxomas constitute about $50 \%$ of all the benign cardiac tumours in adults and are mostly $(>80 \%)$ found in the left atrium. ${ }^{1}$ Systemic embolisation

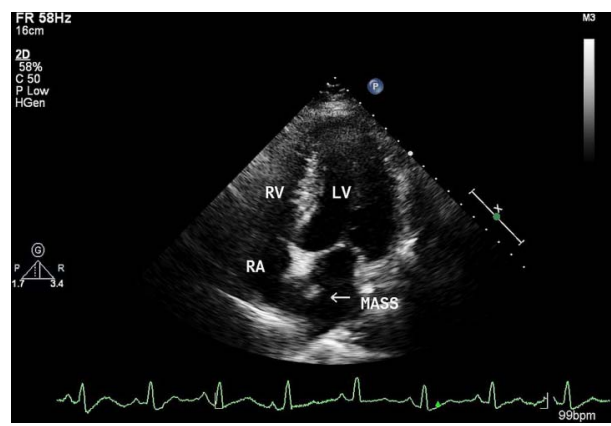

Figure 2 Transthoracic echocardiogram, apical four-chamber view, showing the left atrial mass attached to the interatrial septum near the fossa ovalis. LV, left ventricle; $R A$, right atrium; $R V$, right ventricle.

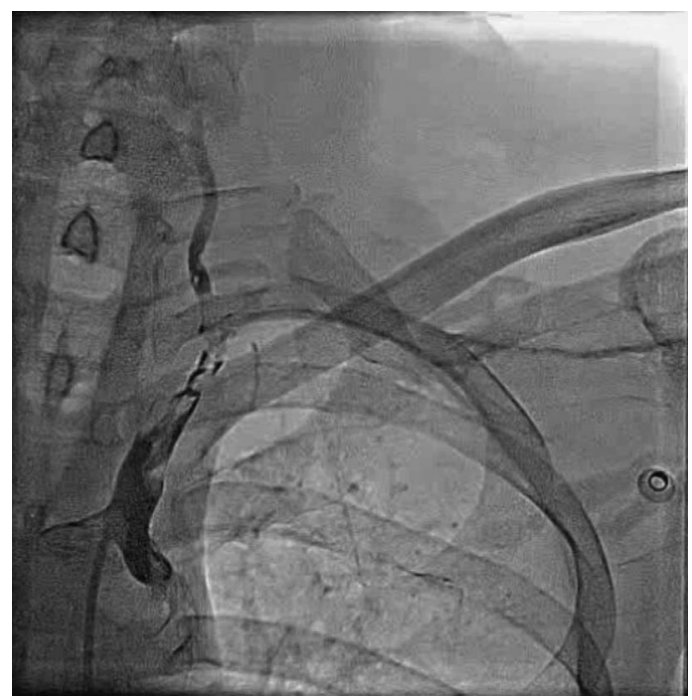

Video 2 Subclavian artery angiography showing filling defects and total occlusion after the origin of the vertebral artery. 


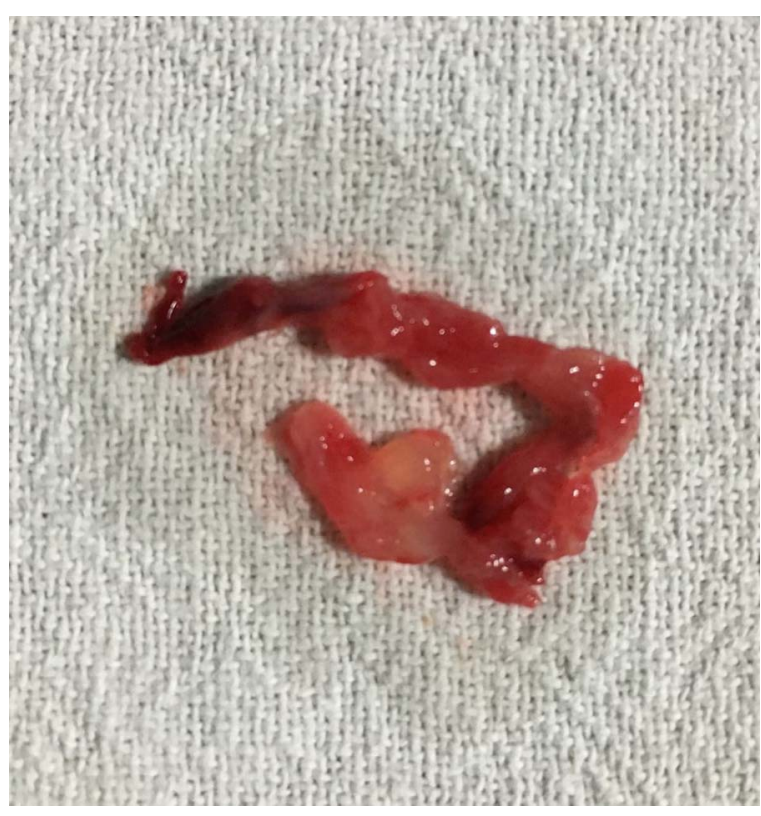

Figure 3 Specimen removed during surgical embolectomy of left upper limb. It was soft and friable with a distinctive gelatinous appearance suggestive of a myxoma.

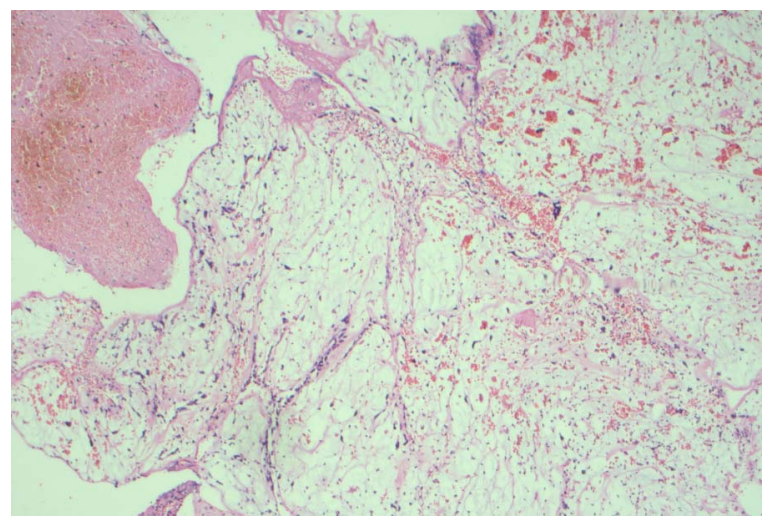

Figure 4 Histopathological examination showing myxoma with spindle cells with slender nuclei embedded in myxoid material with areas of haemorrhage and inflammation $(\mathrm{H} \& \mathrm{E}, \times 40)$. occurs in around 30\% of cases either from tumour fragmentation or complete tumour detachment. Cerebral embolism is the most common site followed by coronary, renal, mesenteric and peripheral arteries. ${ }^{2}$ Embolisation of cardiac myxoma to peripheral arteries leading to acute limb ischaemia has rarely been reported before. ${ }^{3}$ It should always be kept in the differential diagnosis of otherwise healthy patients who present with acute-onset limb ischaemia.

\section{Learning points}

- Cardiac myxoma is the most common benign tumour of the heart and has high potential for systemic embolisation.

- The most common site of embolisation is the central nervous system followed by the coronary, renal, mesenteric and peripheral arteries.

- Embolisation to peripheral arteries causing acute limb ischaemia has rarely been reported before.

- Cardiac myxoma should always be considered as a possible source of embolism in otherwise healthy patients presenting with acute limb ischaemia.

- Management should aim at concurrent removal of both the embolus and cardiac tumour to avoid further embolism.

\section{Competing interests None declared.}

Patient consent Obtained.

Provenance and peer review Not commissioned; externally peer reviewed.

\section{REFERENCES}

1 Ekmektzoglou KA, Samelis GF, Xanthos T. Heart and tumours. Location, metastasis, clinical manifestations, diagnostic approaches and therapeutic considerations. $J$ Cardiovasc Med 2008;9:769.

2 Dias RR, Fernandes F, Ramires FJ, et al. Mortality and embolic potential of cardiac tumors. Arq Bras Cardiol 2014;103:13-18.

3 Chiba K, Abe H, Kitanaka Y, et al. Left atrial myxoma complicated with an acute upper extremity embolism. Ann Thorac Cardiovasc Surg 2012;18:391-4.

\footnotetext{
Copyright 2016 BMJ Publishing Group. All rights reserved. For permission to reuse any of this content visit http://group.bmj.com/group/rights-licensing/permissions.

BMJ Case Report Fellows may re-use this article for personal use and teaching without any further permission.

Become a Fellow of BMJ Case Reports today and you can:

- Submit as many cases as you like

- Enjoy fast sympathetic peer review and rapid publication of accepted articles

- Access all the published articles

- Re-use any of the published material for personal use and teaching without further permission

For information on Institutional Fellowships contact consortiasales@bmjgroup.com

Visit casereports.bmj.com for more articles like this and to become a Fellow
} 